\title{
Mr. and Mrs.
}

\section{Professionalism}

\author{
De er 87 år gamle og glitrer på den globale scenen med sine bøker, artikler og foredrag om \\ profesjonell identitet og legeskap, om hva leger må forstå, kunne, føle og ville for å innfri den \\ stilltiende kontrakten med samfunnet og pasientene. En ny karriere startet da de pensjonerte \\ seg, etter 40 år som henholdsvis ortoped og endokrinolog i Montréal, Canada.
}

Noen ganger kommer man i nærkontakt med folk som er fremragende. Litt urovekkende kan det være, men jeg blir jo nysgjerrig på hva dette «fremragende» består av, hvordan det ble slik, hvordan denne uvanlig dyktige personen ellers er, som medmenneske, kollega, som en alminnelig sårbar kropp på jorden.

Jeg har sett dem på den internasjonale scenen, Richard og Sylvia Cruess, i Boston, Glasgow og Barcelona. Jeg har lest artiklene deres, og boken Teaching medical professionalism som kom i ny utgave i 2016. I år er de mine kolleger ved Centre for Medical Education ved McGill University i Montréal, Canada, hvor jeg er gjesteforsker. Her har de siden 1995 fått en internasjonal karriere innen medisinsk undervisning.

Vi holder til i en gammel herskapsbygning i sentrum, en etterlevning av den engelske overklassen som slo seg opp på tømmer og kornhandel og dominerte det fransktalende Québec fra 1700-tallet. Det er hverdagslig nå, å se de to gamle professorene komme ut av heisen, litt forsiktige og stive til beins, på vei til kontoret hvor tykke bunker av artikler og bøker om medisinsk pedagogikk fyller skrivebord og hyller.

\section{Aldersjustert fordom}

Etter et halvt år i dette miljøet har jeg stadig ikke sluttet å undre meg over disse to, jeg legger spesielt merke til hvordan de tar ordet på fellesmøter, at de kjapt plukker opp nye poenger og kommer med kreative innspill. Hva er så spesielt med det, i et miljø hvor mange har mye å fare med? Jeg må innse at jeg har aldersjusterte fordommer. Jeg undrer meg over at så gamle mennesker er intellektuelt på topp, tar seg selv på fullt alvor, tar sjanser, vil noe og klarer å flette seg vennlig og smart inn i et avansert akademisk miljø hvor flertallet er 50 år yngre enn dem. Hjemme i Norge er slikt knapt tenkelig, vi har en kultur som dyrker ungdom, hvor gamle folk skal ikke tro de er noe. Og siden disse holdningene er preget i oss, blir vi vår egen tidsinnstilte bøddel når pensjonsalderen inntreffer: «70 ja, da må jeg holde en lav profil og huske at jeg er unyttig og ubetydelig. Hvil, spill golf!». Ikke slik her. Provinsen Quebec har lovforbud mot å avsette arbeidstakere på grunn av høy alder. Richard, kalt Dick, er fortsatt i full stilling som professor.

- Jeg holder på fordi jeg merker at jeg bidrar og gjør jobben. Og da er det rimelig at jeg får betalt og har en stillingsbetegnelse

\section{«Leger må forstå sin profesjon slik felles- skapet ser den»}

som gir meg ansvar. Det får meg til å strekke meg, yte mer, akkurat som med yngre folk. Lønn, ansvar og kollegers tillit får frem det beste man har å by på.

\section{Bli kjent med de innfødte!}

Det er tidlig høst, jeg har hatt mitt første faglige innlegg på senteret og presentert nyvinninger ved legestudiet i Bergen. Rommet tømmes. En mann blir igjen, det er Richard Cruess, høy, stram og hvithåret, med blazer, brett i buksen og blå, vennlige øyne. Han stiller seg smilende foran meg.

- Sylvia og jeg ville sette pris på om du og din kone kom til oss på middag på lørdag. Du må jo bli kjent med de innfødte!

Noen dager senere står vi utenfor et ombygd kloster i Montréal sentrum, spor etter en katolisisme som for inntil en generasjon siden dominerte Québec-samfunnet religiøst og kulturelt, med eierskap til all undervisning og alle sykehus. En omfattende sekularisering i 60-årene, kalt «la révolution tranquille», har endret samfunnet. I dag er mange klostre og kirker ombygd til luksusleiligheter, og helsevesenet er offentlig med mange sosialdemokratiske trekk.

En fransktalende concierge i jakke og slips fører oss mellom marmorvegger, messing og palmer til heisen. Leiligheten fyller en halv etasje, rommene er fylt av minner fra et samliv som har vart i snart 65 år. De giftet seg i 1954 og har to barn.

- Vi gjorde noe sprøtt for vår alder, vi investerte i nytt stereoanlegg, sier Dick. - Det gir oss enorm glede! Jeg husker da LP-en kom i 1948, det gjorde musikken tilgjengelig for alle. Og dette er enda deiligere.

Musikk av Mozart flyter i luften, det er Exsultate, Jubilate får vi vite etter hvert, de har begge studert musikk før de begynte på medisin ved Columbia University i 1951. Dick brukte dessuten et år på slimålens biologi, mens Sylvia studerte litteratur.

- Vi har vært privilegerte hele vårt liv. Gode familier med tilstrekkelig penger, kulturell bredde, de beste skolene, fantastiske lærere, og etter hvert spennende jobber blant enestående kolleger, til denne dag. Vi er takknemlige og føler sterk forpliktelse til å bidra med det vi kan, så lenge vi kan være til nytte.

\section{Kvinnelig lege i 1950-årene}

- Hvordan var det å være kvinne i en mannsverden, Sylvia?

- Mange spør, de tror vi ble diskriminert. Men det har jeg aldri merket. Vi var 12 jenter på kullet, og vi ble tatt på alvor. Og det fantes sterke forbilder. En av mine strålende lærere var Virginia Apgar, anestesilegen som utviklet Apgar-skår, som i dag brukes ved alle fødsler. I familielivet har jeg heller aldri vært «undertrykket», som de unge er så opptatt av. Dick og jeg delte livet mens vi studerte, var i turnus sammen og spesialiserte oss samtidig. Begge hadde vakter, plikter, full legejobb. Derfor lærte vi å dele alt hjemme også, det har vi gjort i 64 år. Og nå er vi sammen om interessen for medisinerutdanning og legers profesjonelle identitet. 


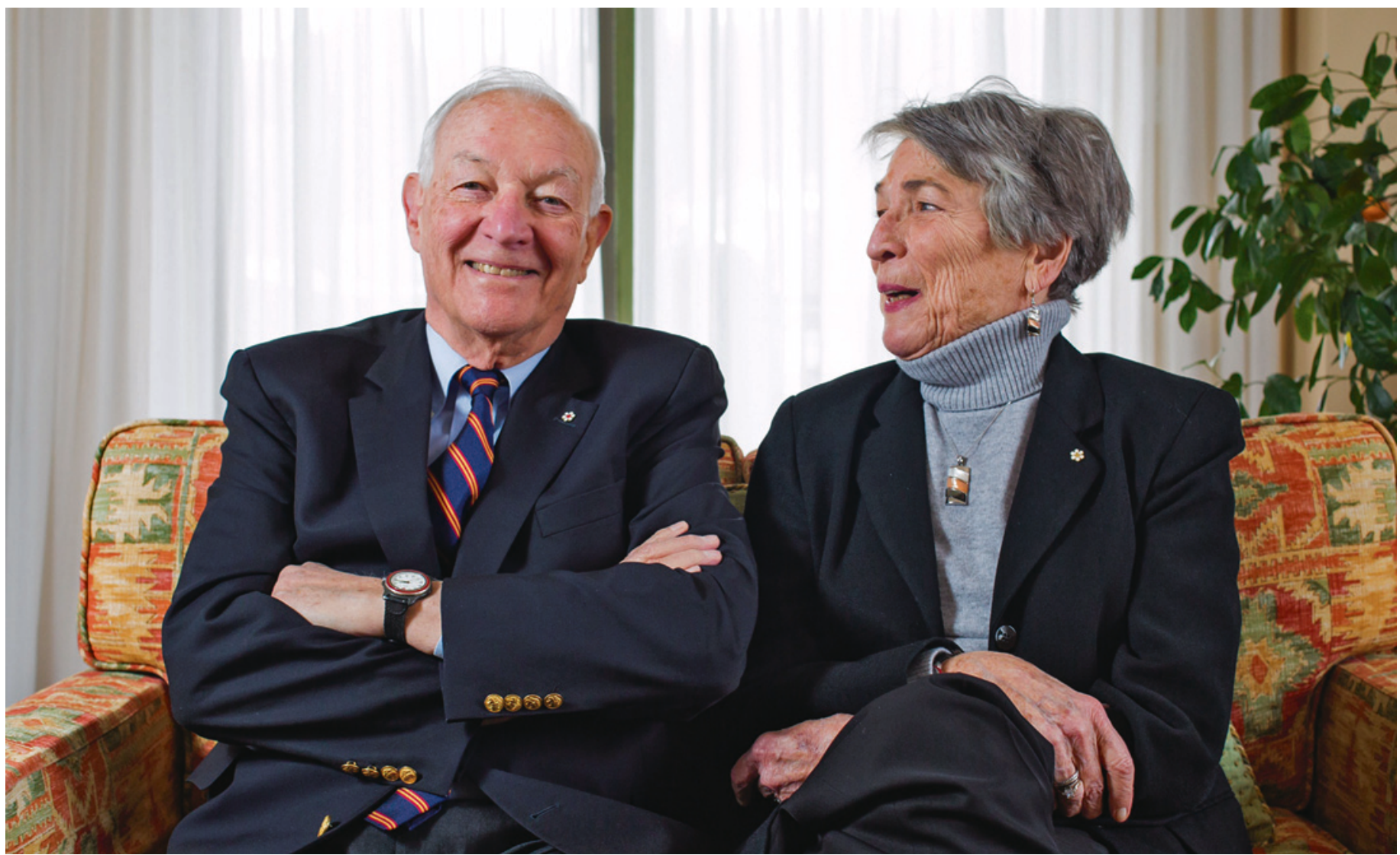

Foto: Selena Phillips-Boyle

\section{Richard L. Cruess}

Født 1929 i Ontario, Canada

- Forskerkarriere som ortoped

- President i American Orthopaedic Research Society og Canadian Orthopaedic Association i 1970-årene

- Dekan ved Det medisinske fakultet, McGill University, 1981-95

- Companion of the Order of Canada, Canadas høyeste æresbevisning, 2014

\section{Sylvia R. Cruess}

Født 1930 i Cleveland, Ohio

- Vassar College 1947-1951

- Spesialist i endokrinologi 1971

- Medisinsk visedirektør, Royal Victoria Hospital, Montréal 1977-95

- Konsulent for Project Professionalism an International Charter, American Board of Internal Medicine, 2000-05 - Officer of the Order of Canada

\section{«Medisinsk profesjonalitet»}

- Hvorfor må vi undervise «profesjonalitet» på legestudiet? Hva vil skje hvis vi ikke gjør det?

- Jeg har levd lenge og sett verden endre seg, sier Dick. - Legeyrket får nye muligheter og nye floker. Legers autonomi og status kan aldri kan tas for gitt - vi må vise at vi oppfyller en stilltiende kontrakt med samfunnet. Det forventes - med rette - at vi som en profesjon av høyt respekterte hjelpere oppfører oss særlig anstendig og omsorgsfullt. Vi må klare å innfri en slik kontrakt i generasjon etter generasjon mens verden forandrer seg. Leger lever i et krysspress hvor mange vil dirigere oss, konkurrere med oss, utnytte oss eller ha flere tjenester enn det er mulig å tilby. Vi må lære unge leger å se seg selv som noe annet enn teknikere og funksjonærer, de må være omsorgsfulle lederskikkelser. Leger må forstå sin profesjon slik fellesskapet ser den og lære å være i ekspertrollen uten å virke nedlatende og uten å la seg manipulere. Det handler om å vedlikeholde tillit. Ikke tilfeldig defineres medisinsk profesjonalitet som «de verdier, væremåter og relasjoner som skaper tillit til leger hos enkeltpasienter og i samfunnet».

Dick er intenst henvendt til meg mens han snakker, men stemmen er lavmælt. Sylvia nikker ivrig til det ektefellen sier. Jeg skyter inn: - Verken deres eller min generasjon leger fikk undervisning i profesjonalitet, ordet var ukjent. Betyr det at vi gikk glipp av noe viktig?

\section{Legene var opphøyet}

- Ja. Legestudenter må lære om legeinstitusjonen, om hva en profesjon er, og om legers symbolske rolle som helbredere, så de kan forstå hvordan de blir sett av andre. Sylvia og jeg vokste opp i USA i 30- og 40årene, da klasseskiller og hierarki var naturlig. Når en lege kom inn i rommet, reiste alle sykepleierne seg. Legene hadde atskilt kantine til ut i 60-årene. «Lege» var noe opphøyet, og det var ikke normalt for den tidens generasjoner å kritisere eller kontrollere overklassen, maktmenneskene, ekspertene. Derfor ble vi ikke kritiske innad heller. Hvem skulle stått opp og fått gehør for at leger måtte undervises i «profesjonalitet» og «legeskap»? Alt syntes jo å være den beste av alle tenkelige verdener, liv ble reddet, og forskningen frembrakte mirakler på løpende bånd. Slik var stemningen da vi studerte medisin. Og derfor foregikk det ingen kritisk refleksjon. 
- Historisk sto legestanden på høyden av sin makt da dere var unge. Og noen misbrukte tilliten, som i Tuskegee-skandalen hvor svarte menn med syfilis ikke fikk behandling, slik at man kunne studere sykdommens naturlig forløp. Og legenes rolle i Holocaust var jo ubehagelig fremtredende. Hvordan var holdningene da dere studerte medisin?

\section{Rollemodeller og konvensjoner}

- Legene som ble utdannet i Nord-Amerika i vår tid, var stort sett hvite middelklassemenn med en jødiskkristen kulturell bakgrunn og oppdragelse. Den religiøse dimensjonen var ganske sterk, og med den fulgte en felles moralkodeks. Vi var ikke edlere enn nå, grådighet og narsissisme har alltid vært fallgruver i dette yrket. Men vi ble holdt $\mathrm{i}$ ørene av konvensjoner og tett sosial kontroll. Vi var få, og vi ble ledet inn i faget av fantastiske rollemodeller som vi kopierte både bevisst og ubevisst. Vi ble kjent med lærerne som mennesker, de kliniske praksisperiodene strakk seg over måneder, og pasientene lå inne i lang tid, slik at vi også ble kjent med dem, sykdommenes forløp og konsekvensene av våre avgjørelser.

- Det vi nå kaller «profesjonalitet», var ikke et tema, man snakket derimot om en leges «karakter» og mente stort sett det samme: at legeyrket krever integritet, vilje til å sette andres ve og vel over egne behov, evne til å være selvkritisk og forvalte privilegier og makt uten å misbruke tilliten folk har til leger. I dag er mye endret. Leger rekrutteres fra kulturer med sprikende religiøse baktepper, divergerende syn på hva personer har krav på, og hva den enkelte skylder fellesskapet. Medisinen er også blitt mer av en industri, med fabrikklignende produksjonsprosesser, mindre autonomi i jobben, høyt tempo og lite nærhet mellom veileder og nybegynner, lege og pasient. Men jobben som lege kan ikke håndteres ved et samlebånd. Vi må bruke skjønn i stive systemer, være kritisk informert om vitenskapelig kunnskap, finne balansen mellom jobb og liv og samtidig møte medmennesker i deres lidelse. Derfor trenger vi ikke legefunksjonærer, men tenkende profesjonsutøvere. De må vi utdanne. Det er krevende. Er vi gode forbilder? Mestrer vi selv det vi ønsker å formidle?

\section{Lærte ikke å reflektere}

- Vi fikk opplæring på fremragende læresteder - Princeton, Columbia, McGill. Hvis noen skulle lært kritisk tenkning i faget, så måtte det vært oss. Men vi må dessverre slå fast at vi aldri ble satt i en læringssituasjon hvor formålet var å få oss til å reflektere. Og det skjønte vi ikke før vi som pensjonister begynte å lese om profesjonalitet, læring, dannelse. Det var en kraftig oppvåkning til en skyggeside ved fagkulturen.

Siden har vi arbeidet for å vekke andre. Og vi tror det har virket.

- Hva mener dere med at dere ikke lærte å reflektere? Leger må jo reflektere for å løse oppgavene?

\section{Uforståtte følelser}

Dick griper ordet raskt, slik han har for vane. Sylvia ser ut som hun vil si noe, men smiler bare.

- Vi reflekterte i behandlingssituasjonene, det er selvsagt viktig. Men det er så mye annet å forstå i yrket vårt. At pasientmøtene vakte sterke følelser i oss var fullstendig for-

\section{«Grådighet og narsis- sisme har alltid vært fallgruver i dette yrket»}

tiet, vi måtte ikke vise «svakhet». Da jeg selv ble overveldet av følelser, var det svært vanskelig, jeg forsto ikke meg selv og var redd for ikke å passe i legeyrket. Ingen hjalp oss til å møte død og lidelse. Som sisteårsstudent tok jeg meg av en mann som hadde hatt et stort hjerteinfarkt. Jeg var i akuttmottaket, forsto at det bar mot slutten og la stetoskopet på brystet hans. Hjertet sluttet å slå. Jeg var 22 år og hadde ikke mye erfaring med døden. Det var en svært emosjonell opplevelse. Fire år senere fikk min far lungekreft. Jeg var enebarn, og han var min beste venn. Jeg kjørte til sykehuset i New Jersey i tett snødrev og tenkte på at far var døende. Jeg gråt hele veien. Siden har jeg ikke grått. Jeg vet ikke hvorfor den gråten var så rensende. Kan du forklare det? Har du lært noe om sorg? I vår tid var det helt taust. Det er bedre nå, på legeutdanningen, men vi har ennå langt å gå. Hvis vi ikke forstår følelser, og ikke oss selv, hvordan skal vi kunne forstå pasientene?

Uprofesjonelt å bli glad i pasientene? Sylvia tar ordet, hun dirrer litt i stemmen, ser meg rett i øynene:
- Min verste opplevelse som lege var da jeg måtte gå fra en pasient fordi jeg ikke klarte å være der. Jeg måtte forlate rommet, jeg holdt på å bryte sammen og klarte ikke å opptre profesjonelt.

- Mener du at du holdt på å begynne å gråte?

- Ja, jeg gjør vel det. Jeg har skammet meg over det $i$ alle år etterpå. Jeg var en erfaren lege, jeg hadde bygd opp en endokrinologisk poliklinikk. Pasientene kom igjen og igjen, og jeg ble glad i dem. En av diabetikerne var en fransk-kanadisk gutt, jeg traff ham som 19-åring da han amputerte det ene beinet. Vi fikk bedre kontroll på diabetesen, men det kom jo nye komplikasjoner, med synet og nyrene. Jeg hadde kjent ham i over 20 år da han fikk nyresvikt og var helt oppsvulmet i kroppen. Noen hadde satt opp et drypp uten at han hadde diurese. Jeg skjønte at han var i ferd med å dø. Og så klarte jeg ikke å være en lege for ham, jeg forlot ham og fikk bare sagt til noen at de måtte fjerne det intravenøse. Jeg sviktet ham.

Jeg prøver forsiktig å protestere - er ikke følelser tillatt $\mathrm{i}$ den profesjonelle legerollen hun prøver å forme? Hun hører på meg, smiler høflig og sier «yes, I guess you are right», men rister på hodet og ser trist ut.

\section{Å ta form}

Jeg rusler tilbake til mitt kontor under skråtaket i tredje etasje og kikker utover skyskraperlandskapet i Montréal sentrum. Det er snø, 20 kuldegrader ute, og medisinstudenter i flokk basker seg frem på fortauet. Jeg tenker på hvordan de formes av utdanningen og strekker seg for å bli gode nok leger i egne øyne. Og jeg tenker på Sylvias siste fortelling. Hvorfor skammer hun seg over sin medfølelse med pasienten hun var glad i? Er pregingen av den unge Sylvia i 50-årene sterkere enn 20 års intellektuell analyse av legerollen? Jeg ser ut på de leende ungdommene. De vet ikke at de formes i en verden hvor handling snakker høyere enn ord.

\section{Edvin Schei}

edvin.schei@uib.no 